\title{
CHEMICAL AND PHYSICAL-HYDRIC CHARACTERISATION OF A RED LATOSOL AFTER FIVE YEARS OF MANAGEMENT DURING THE SUMMER BETWEEN-CROP SEASON ${ }^{(1)}$
}

\author{
José Fausto Guimarães Silva ${ }^{(2)}$, Eduardo da Costa Severiano ${ }^{(3)}$, Kátia Aparecida de Pinho \\ Costa $^{(3)}$, Vinícius de Melo Benites ${ }^{(4)}$, Wellingthon da Silva Guimarães Júnnyor ${ }^{(5)}$ \& José \\ Carlos Bento ${ }^{(6)}$
}

\begin{abstract}
SUMMARY
Agricultural production systems that include the production of mulch for notillage farming and structural improvement of the soil can be considered key measures for agricultural activity in the Cerrado region without causing environmental degradation. In this respect, our work aimed to evaluate the chemical and physical-hydric properties of a dystrophic Red Latosol (Oxisol) in the municipality of Rio Verde, Goias, Brazil, under different soil management systems in the between-crop season of soybean cultivation five years after first planting. The following conditions were evaluated:Brachiaria brizantha cv. Marandu as a cover crop during the between-crop season; Second crop of maize intercropped with Brachiaria ruziziensis; Second crop of grain alone in a no-tillage system; Fallow soil after the soybean harvest; and Forest (natural vegetation) located in an adjacent area. Soil samples up to a depth of $40 \mathrm{~cm}$ were taken and used in the assessment of chemical properties and soil structure diagnostics. The results demonstrated that the conversion of native vegetation areas into agricultural fields altered the chemical and physicalhydric properties of the soil at all the depths evaluated, especially up to $10 \mathrm{~cm}$, due to the activity of root systems in the soil structure. Cultivation of B. brizantha as a cover crop during the summer between-crop season increased soil water availability, which is important for agricultural activities in the region under study.

Index term: Brachiaria, crop succession, no-tillage, least limiting water range, water availability.
\end{abstract}

(1) Excerpt from the Master's Dissertation of the first author at Instituto Federal Goiano (IFGoiano). Received for publication on February 19, 2013 and approved on June 2, 2014.

(2) Doctoral student in Agronomy, IFGoiano, Campus Rio Verde. Rod. Sul Goiana, km 01, Zona Rural. Caixa Postal 66. CEP 75901-970 Rio Verde (GO), Brazil. E-mail: jfausto_ufrrj@yahoo.com.br

(3) Professor D3, IFGoiano, Campus Rio Verde. E-mail: eduardo.severiano@ifgoiano.edu.br, katiazoo@hotmail.com

(4) Researcher, Embrapa Solos. Rua Jardim Botânico, 1.024, Jardim Botânico. CEP 22460-000 Rio de Janeiro (RJ), Brazil. E-mail: vmbenites@gmail.com

(5) Master student in Agronomy, IFGoiano, Campus Rio Verde. E-mail: wellingthon.agro@gmail.com

(6) Master student in Agriculture, Universidade de Rio Verde. Fazenda Fontes do Saber. Caixa Postal 104. CEP 75.901-970 Rio Verde (GO). E-mail: josecarlos.bento@gmail.com 


\title{
RESUMO: CARACTERIZAÇÃO QUÍMICA E FÍSICO-HÍDRICA DE UM LATOSSOLO VERMELHO, APÓS CINCO ANOS DE MANEJO, NO PERÍODO DE ENTRESSAFRA DE VERÃO
}

\begin{abstract}
Sistemas de produção agrícola que contemplam produção de palhada para o plantio direto e que atuam na melhoria estrutural do solo podem ser considerados medidas-chave para a atividade agrícola na região do Cerrado, sem a contrapartida da degradação ambiental. Nesse sentido, este trabalho objetivou avaliar os atributos químicos e físico-hídricos de um Latossolo Vermelho distrófico do município de Rio Verde, Goiás, sob diferentes sistemas de manejo do solo na entressafra da cultura da soja, após cinco anos da sua implantação. Foram avaliados: Brachiaria brizantha cv. Marandu como planta de cobertura na entressafra; Safrinha de milho consorciada com Brachiaria ruziziensis; Safrinha de grãos solteira em sistema plantio direto; Solo sob pousio, após a colheita da soja; e Mata (Vegetação Natural), situada ao lado. Foram feitas amostragens de solo até $40 \mathrm{~cm}$ de profundidade, utilizadas na avaliação dos atributos químicos e no diagnóstico estrutural dele. Os resultados demonstraram que conversão de áreas de vegetação nativa em campos de agricultura alterou os atributos químicos e físico-hídricos do solo em todas as profundidades avaliadas, principalmente até $10 \mathrm{~cm}$, em razão da ação do sistema radicular sob a estrutura do solo. O cultivo de B. brizantha como planta de cobertura no período de entressafra das culturas de verão aumentou a disponibilidade hídrica do solo, assumindo relevância para a atividade agrícola na região em estudo.
\end{abstract}

Termos de indexação: Brachiaria, sucessão de culturas, sistema plantio direto, intervalo hídrico ótimo, disponibilidade hídrica.

\section{INTRODUCTION}

In recent decades, Brazil has established itself as a major global agricultural power due to the incorporation of intensive crop technologies related to the use of inputs and the implementation of mechanised operations in the production process, thus enabling the expansion of the agricultural frontier into regions hitherto marginalised, especially the Cerrado region (Severiano et al., 2013). In this region, increasing economic pressure to open new agricultural areas to produce commodities is observed because soils with high agricultural potential overlie these lands, such as Latossolos (Oxisol - hereinafter Latosol) (Reatto et al., 2007).

In addition, Brazil is quickly surpassing other countries in the production and export of food, and it is establishing a sustainable production system that will help to feed a growing world population (Tollefson, 2010). Therefore, agricultural activity has been extensively studied by several researchers, focusing on the intensification of soil use during the betweencrop period of summer crops (Maia et al., 2014) and on improvements in soil properties. Such systems focus agricultural competitiveness on convergence to the mitigation of the greenhouse effect under the lowcarbon agriculture plan with the goal of adopting sustainable production technology in more than 25 million hectares (Cerri et al., 2012).

In this context, the no-tillage conservation system is important. This system is based on minimum soil disturbance, which is restricted to the planting furrow. The no-tillage system also makes use of crop rotation and uses herbicides for weed control, and it involves the formation and maintenance of mulch, which results in slower decomposition rates and the accumulation of organic matter on the surface.

Due to the feasibility of intercropping with forage plant species, particularly Brachiaria (Brachiaria (Trin.) Griseb. spp. syn. Urochloa P. Beauv. spp.) planted during the second crop season, the no-tillage system further stands out by providing increased protection against erosion factors (Andrade et al., 2009) and by maintaining soil water availability through reduction of the evaporation of water stored in the profile (Blainski et al., 2012).

Moreover, the flat topography makes the Cerrado region potentially suitable for the development of mechanised agriculture, as intensive traffic of machinery on areas of inadequate soil moisture has been observed. Under these conditions, the soil has low load-bearing capacity, thus making it vulnerable to compaction (Severiano et al., 2011).

Soil compaction has its origin in the compression of unsaturated soil, during which bulk density increases due to the reduction in the volume of pores filled with air. Soil compaction is responsible for reducing soil aeration and increasing soil resistance to root penetration, thereby altering the availability of oxygen, water and nutrients because their mobility depends on the fluxes that occur in the pore space (Silva et al., 2006; Kadžienè et al., 2011). Thus, compaction can reduce crop yields by altering the chemical, physical-hydric and even biological properties of the soil (Magalhães et al., 2009; Carneiro et al., 2009; Silva et al., 2011).

Considering the importance of soybean (Glycine $\max$ ) production in global agribusiness, it is necessary to develop management systems that include mulch 
production for no-tillage and that also act to mitigate the harmful effects of heavy machine traffic on soil conditions during summer cropping (Beutler et al., 2008; Chioderoli et al., 2012), without substituting the crops mentioned.

With the intensification of land use, crop rotation restricted to the between-crop season, associated with crop conservation systems may be the key to maintaining agricultural sustainability by reducing the pressure to open new crop areas, which thereby increases the preservation of biodiversity in the region (Galharte \& Crestana, 2010).

Given the above, the aim of this study was to evaluate the chemical and physical-hydric properties of a Red Latosol of the municipality of Rio Verde, Goias, Brazil under different soil management systems in the between-crop season of soybean cultivation five years after it was first planted.

\section{MATERIALS AND METHODS}

The study was conducted in areas belonging to the "Technology Centre" (CTC) of the "Agroindustrial Cooperative of Rural Farmers of Southwest Goias" (Cooperativa Agroindustrial dos Produtores Rurais do Sudoeste Goiano - COMIGO) located in the municipality of Rio Verde, Goias (latitude $17^{\circ} 45^{\prime} \mathrm{S}$, longitude $51^{\circ} 02^{\prime} \mathrm{W}$ and altitude of $840 \mathrm{~m}$ ) and in the Laboratory of Soil Physics of the Federal Institute of Education, Science and Technology Goiano (Instituto Federal de Educação, Ciência e Tecnologia Goiano IF Goiano) at the Rio Verde Campus.

Adopting the criteria proposed by Köppen (1931), the climate is classified as tropical savannah with dry winters and rainy summers (Aw) with a mean annual rainfall greater than $1,600 \mathrm{~mm}$. The veranico (unseasonable warm dry weather) climate phenomenon occurs in the rainy season, and it usually lasts 10 to 15 days and may eventually extend for up to 30 days.

The experiment was conducted in a dystrophic Red Latosol (Oxisol) according to Embrapa (2013) of oxidicgibsitic mineralogy (Table 1), involving different systems of soil management and following a randomised block design.
Before beginning the experiment, the area had been used for grain production in a no-tillage system for 20 years. In 2007, the area was divided into experimental plots $(20 \times 10 \mathrm{~m})$, and complete soil amendment was performed to eliminate the history of strain. Additional details about the experimental procedures have been described by Caetano et al. (2012).

Four management systems were evaluated during the between-crop season of soybean cultivation, as described in table 2.

The treatments evaluated consisted of the following management systems during the between-crop season of soybean cultivation:

- B. brizantha: Cultivation of Brachiaria brizantha cv. Marandu as a cover crop (un-grazed) during the between-crop season of soybean cultivation;

- Intercropped second crop: Second crop of maize (Zea mays) intercropped with Brachiaria ruziziensis. After the harvest of the second crop, the forage was managed for mulch production (un-grazed) during the betweencrop season of soybean cultivation;

- Single second crop: Grain production in the second crop under no-tillage. Soil under fallow after harvest of second crop;

- Fallow: Soil under fallow after soybean harvest with desiccation of the weed community;

- Forest: Area of natural vegetation characterised by the physiognomy of the Cerrado savannah with thick leaf litter and without human intervention in an adjacent area situated $160 \mathrm{~m}$ from the experiment (used as a reference).

The summer crop evaluated was sown in October 2011, approximately 30 days after desiccation of the plots, using the Monsoy M7211 RR soybean variety in an early cycle. In December 2011, during the flowering of the soybean crop, soil was sampled between the crop rows and in the centre of each plot at the depths of 0-5, 5-10, 10-20, 20-30 and 30-40 cm. An auger was used for disturbed samples, and an Uhland sampler (cylinders with a diameter of $6.40 \mathrm{~cm}$ and a height of $5.00 \mathrm{~cm}$ ) was used for the undisturbed samples. A total of 80 samples (four between-crop season management systems $\times$ four plots $\times$ five depths) were collected, as well as 20 samples in four replicates in the forested area at the five aforementioned depths.

Table 1. Physical and chemical characterisation of the dystrophic Red Latosol cultivated under different soil use and management systems in the between-crop season of soybean cultivation

\begin{tabular}{|c|c|c|c|c|c|c|c|c|c|}
\hline Depth & $P d^{(1)}$ & Clay $^{(2)}$ & Silt & Sand & $\mathrm{SiO}_{2}^{(3)}$ & $\mathrm{Al}_{2} \mathrm{O}_{3}$ & $\mathrm{Fe}_{2} \mathrm{O}_{3}$ & $\mathbf{K i}$ & $\mathbf{K r}$ \\
\hline $\mathrm{cm}$ & $\mathrm{kg} \mathrm{dm}{ }^{-3}$ & & & 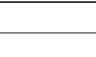 & $\mathrm{g}^{-1}$ & . & & & \\
\hline $0-20$ & 2.66 & 355 & 67 & 578 & 87 & 205 & 63 & 0.72 & 0.60 \\
\hline $20-40$ & 2.65 & 379 & 62 & 559 & 92 & 213 & 78 & 0.73 & 0.60 \\
\hline
\end{tabular}

(1) Pd: Particle density, determined by the volumetric flask method (Embrapa, 2011); mean of 16 repetitions. ${ }^{(2)}$ Determined by the pipette method (Embrapa, 2011); mean of 16 repetitions. ${ }^{(3)}$ Oxide content; mean of three repetitions. Ki: molecular relationship $\left(\mathrm{SiO}_{2} / \mathrm{Al}_{2} \mathrm{O}_{3}\right)$; Kr: molecular relationship $\mathrm{SiO}_{2} /\left(\mathrm{Al}_{2} \mathrm{O}_{3}+\mathrm{Fe}_{2} \mathrm{O}_{3}\right)$. 
Table 2. History of management in the between-crop season of soybean cultivation in a dystrophic Red Latosol

\begin{tabular}{ccccc}
\hline \multirow{2}{*}{ Crop year } & \multicolumn{4}{c}{ Management system } \\
\cline { 2 - 5 } & B. brizantha & Intercropped second crop & Single second crop & Fallow \\
\hline $2007 / 08$ & Soil amendment ${ }^{(1)}$ & Soil amendment & Soil amendment & Soil amendment \\
$2008 / 09$ & B. brizantha & Spontaneous vegetation & Millet & Weed community \\
$2009 / 10$ & B. brizantha & B. ruziziensis & Sorghum & Weed community \\
$2010 / 11$ & Maize + B. brizantha & Maize + B. ruziziensis & Maize & Weed community \\
$2011 / 12$ & B. brizantha & Maize + B. ruziziensis & Maize & Weed community \\
\hline
\end{tabular}

(1) Soil amendment through disking and incorporation of lime amendment and fertiliser by mouldboard plough to a $30 \mathrm{~cm}$ depth only at the beginning of the experiment. Adapted from Caetano et al. (2012).

The undisturbed samples were wrapped in PVC film and prepared in the laboratory. The samples were saturated by capillarity for $48 \mathrm{~h}$. The samples were then subjected to Matric Potentials of -2, -4, -6, -33 and $-1.500 \mathrm{kPa}$ via drying for determination of pore size distribution.

Subsequently, the water content of the soil was adjusted (ranging from 0.03 to $0.40 \mathrm{dm}^{3} \mathrm{dm}^{-3}$ ), and the sample was subjected to a penetrometer test utilising a MARCONI-MA 933 bench penetrometer with a constant velocity of $0.1667 \mathrm{~mm} \mathrm{~s}^{-1}$ and a rod ( $3 \mathrm{~mm}$ base cone and semi-angle of $30^{\circ}$ ) equipped with a load of $50 \mathrm{kgf}$ connected to a receiver coupled to a computer to record the readings via the proprietary software of the equipment.

The samples were then dried in an oven at $105^{\circ} \mathrm{C}$ for $48 \mathrm{~h}$ to determine the bulk density $(\mathrm{Bd})$ of the soil by the volumetric ring method (Embrapa, 2011). Total porosity (TP) was determined by equation 1 :

$$
T P=[1-(B d / P d)]
$$

The pore size distribution was based on equation 2, proposed by Bouma (1991):

$$
D=4 \sigma \cos \theta / \Psi_{m}
$$

where $D$ is the pore diameter $(\mathrm{mm}) ; \sigma$ is the surface tension of water $\left(73.43 \mathrm{kPa} \mu \mathrm{m}\right.$ at $\left.20^{\circ} \mathrm{C}\right) ; \theta$ is the contact angle between the meniscus and the capillary tube wall (considered as 0); and $\Psi_{m}$ is the water tension in the soil $(\mathrm{kPa})$.

The least limiting water range (LLWR) was determined considering the following upper limits: the amount of soil water retained in the matric potential of $-6 \mathrm{kPa}$, considered as the field capacity $\left(\theta_{\mathrm{FC}}\right)$, or the amount where the air-filled porosity $\left(\theta_{\mathrm{AP}}\right)$ is $10 \%$. The lower limits were as follows: the amount of water retained at $1,500 \mathrm{kPa}$, the permanent wilting point $\left(\theta_{\mathrm{PWP}}\right)$, and/or the amount of water corresponding to the penetration resistance of $2.5 \mathrm{MPa}\left(\theta_{\mathrm{PR}}\right)$ (Severiano et al., 2011).

The disturbed soil samples were air-dried and passed through a 2 -mm sieve, thus obtaining the airdried fine soil. These samples were utilised to obtain the chemical properties of the sorption complex and organic matter in the soil according to Embrapa (2011).

The results of the chemical and physical-hydric properties were subjected to analysis of variance for randomised block designs according to the statistical model described in equation 3 :

$$
x_{i j}=m+t i+b_{j}+e_{i j}
$$

where $x_{i j}$ is the observed value in the plot that received treatment $i$ in block $j ; \mathrm{m}$ is the mean of the population; $t_{i}$ is the effect of treatment $i$ applied to the plot; $b_{j}$ is the effect of block $\mathrm{j}$, where the plot is found; and $e_{i j}$ is the effect of the factors not controlled for in the plot.

Comparisons of the means were performed using Tukey's test at $5 \%$ utilising SISVAR software (Ferreira, 2011).

\section{RESULTS AND DISCUSSION}

The largest changes in the components of the soil sorption complex occurred up to a depth of $20 \mathrm{~cm}$ in all the soybean crop systems evaluated, as shown in table 3 . This result can be attributed to greater soil fertility compared to native forest, which was likely due to the chemical amendments and previous incorporation at the time of planting annual crops. The management systems had little influence on the chemical properties of the soil due to the absence of soil tillage after implementation of the experiment.

The increase in the $\mathrm{pH}$ values and in the concentrations of $\mathrm{Ca}$ and $\mathrm{Mg}$ reached the deeper layers (20-30 and $30-40 \mathrm{~cm}$, respectively; table 3 ). Consequently, base saturation (V) had similar values of approximately $50 \%$ up to $30 \mathrm{~cm}$, which is considered adequate for soybeans, but aluminium saturation $(m)$ was classified as low in all systems of soil management during the between-crop season (Sousa \& Lobato, 2004). These results were indicative of the effect of the initial incorporation of soil amendments by mouldboard plough to $30 \mathrm{~cm}$ or even the translocation of these nutrients into deeper layers, which was in agreement with the results reported by Oliveira et al. (2004). 
Table 3. Chemical properties and soil organic matter (SOM) content of the dystrophic Red Latosol at five depths under different soil use and management systems during the between-crop season of soybean cultivation

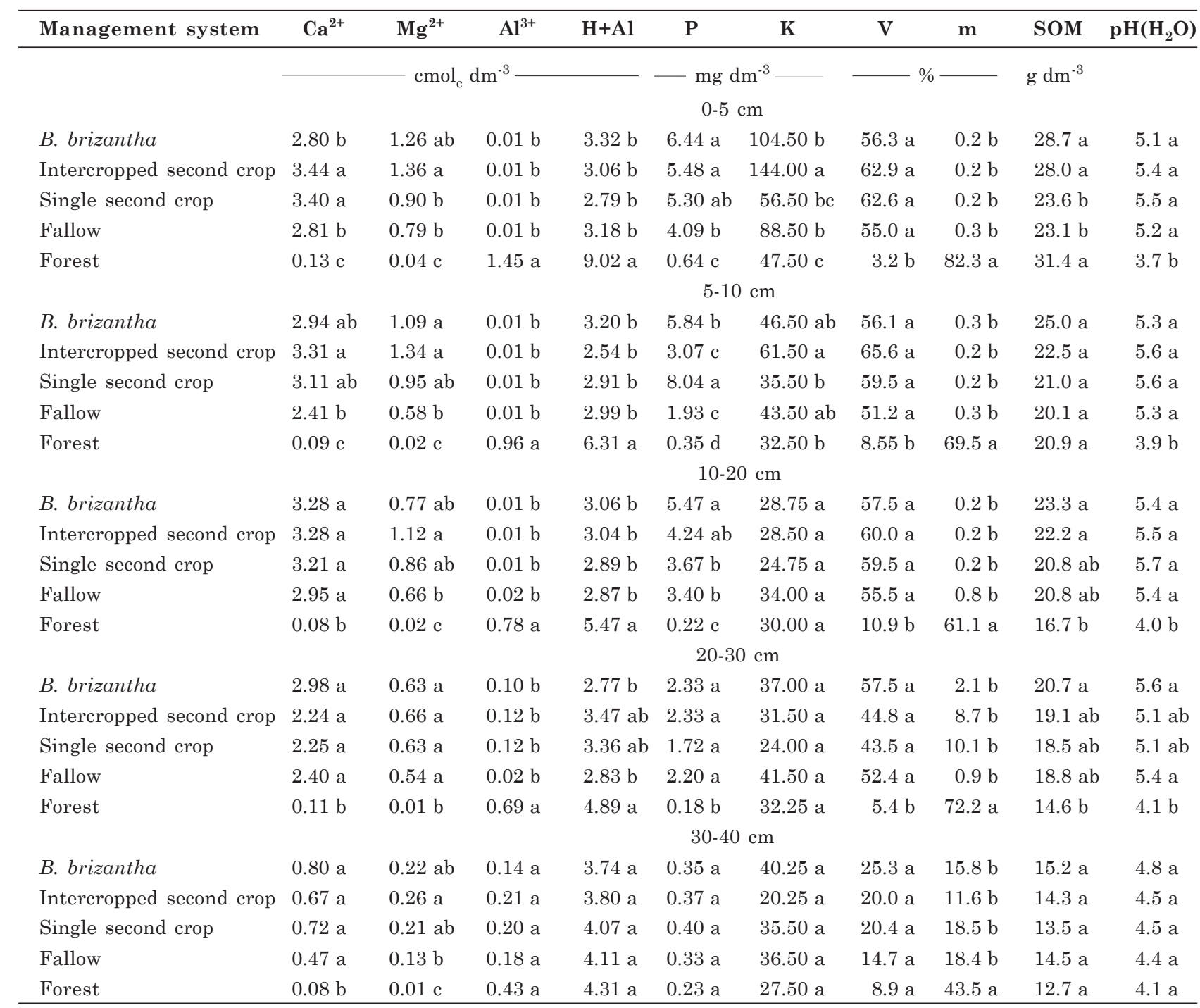

V: base saturation; m: Al saturation; SOM: soil organic matter. Within each depth, the means that have the same letter in the columns do not differ from each other according to Tukey's test $(p<0.05)$.

However, it is important to note that in no-tillage systems combined with maintenance of vegetation cover, elements transported in the soil by diffusion and organic matter tend to accumulate in the upper soil layers, and decomposition promotes improvement of soil fertility (Nascente et al., 2013).

Accordingly, concentrations of $\mathrm{P}$ and $\mathrm{K}$ were observed in these upper layers, especially in systems with Brachiaria (Table 3). These concentrations may be due to the use of grasses with extensive root systems, associated with the constant renewal of adventitious roots and nutrient cycling, which reduce phosphate adsorption by soil particles.

According to Nascente \& Crusciol (2012), the use of forage grasses of the genus Brachiaria is beneficial to farmers and interesting to researchers due to the large amount of residues produced and because the production system is maintained permanently alive during the between-crop season (perennial). In systems involving these grasses, it is suggested that large quantities of $\mathrm{K}$ are taken up because of the considerable capacity of the grasses in recycling this nutrient, thus increasing its content in the surface layers of cultivation (Garcia et al., 2008). This process was evident in crops cultivated in the between-crop season (second crop) intercropped with B. ruziziensis, which had the highest concentrations of $\mathrm{K}$ in the soil (Table 3).

For McNeill \& Penfold (2009), the insertion of species by rotation or by intercropping that are able to use P from poorly soluble sources has been a 
successful strategy for improving P use efficiency in production systems, which may also contribute to the cycling of this nutrient. In this context, it would be good to take advantage of this strategy through the Brachiaria species used in the cropping systems evaluated.

Due to initial preparation with the mouldboard plough, $\mathrm{P}$ levels were higher in all the systems compared to the forest up to a depth of $30 \mathrm{~cm}$ (Table 3 ). The higher P levels may be attributed to the increased mobilisation of the soil in these systems, which uniformly distributed the $\mathrm{P}$ contained in the fertilisers applied prior to the implementation of the experiment in the upper layer (Silveira \& Stone, 2001).

At the depth of $0-5 \mathrm{~cm}$, the content of soil organic matter (SOM) in systems with Brachiaria in the between-crop season showed similar values to those of the forest, and higher values than those of the fallow and single second crop systems; and the SOM content in systems with Brachiaria in the between-crop season showed higher values than the other systems in the deeper layers $(10-30 \mathrm{~cm})$. These results agreed with those of Nascente et al. (2013) and Schiavo et al. (2011), who showed, in general, the potential of cultivating Brachiaria as a soil cover crop to provide soil carbon levels closer to those of the Cerrado vegetation. Andrade et al. (2009) also obtained similar results with the use of marandu grass (B. brizantha) as a cover crop in no-tillage systems.

An increase in the $\mathrm{P}$ and SOM contents (Table 3) was observed as land use in the between-crop season intensified (fallow < single second crop < intercropped second crop $=B$. brizantha), particularly up to a depth of $20 \mathrm{~cm}$. These results corroborated those found by Jakelaitis et al. (2008), and they suggest increased yields of summer crops due to the adoption of intensive production systems, particularly as a result of mulch decomposition from grasses cultivated in the betweencrop season and, consequently, the recycling of nutrients in the soil-plant system (Pacheco et al., 2011).

The management practices adopted in integrated systems using Brachiaria species improve the chemical and physical properties of the soil (Silva et al., 2011; Chioderoli et al., 2012). In addition to improving fertility (Table 3 ), the aggressiveness of the root system of some forage plants has the potential to recuperate the structural quality of the soil (Lima et al., 2012b), as indicated by the physical-hydric properties in table 4 , especially with respect to the cultivation of $B$. brizantha during the between-crop season. These results demonstrated that soil use under the study conditions promoted changes throughout the $0-20 \mathrm{~cm}$ layer, but the main effects were observed at depths up to $10 \mathrm{~cm}$.

Even with the increase in $\mathrm{Bd}$ due to the reduction of TP in all management systems up to $20 \mathrm{~cm}$, macropores were observed to have values higher than those considered to be limiting of soil functions $\left(0.10 \mathrm{dm}^{3} \mathrm{dm}^{-3}\right)$ (Oliveira et al., 2007). Conversely, $B$. brizantha decreased $\mathrm{Bd}$ values in the soil up to $10 \mathrm{~cm}$ due to its aggressive and voluminous root system. Management systems using $B$. brizantha are a viable strategy for the improvement of soil structure in the medium term (five years) when consolidation of the conservation cultivation systems occurs.

These results were in agreement with those of Flávio Neto (2012), who reported that the cultivation of $B$. brizantha during the between-crop season provides biological decompaction to the soil, increasing water availability for the subsequent soybean crop, and that cultivation of $B$. ruziziensis shows limited potential for physical soil recovery. In the present study, although intercropped B. ruziziensis cultivation occurred for three previous years (Table 2), the pattern observed was similar to that of the fallow and single second crop systems (Table 4).

This structural improvement is an advantage of using $B$ brizantha in between-crop season management, especially when the high utilisation of B. ruziziensis for mulch formation in the Cerrado region is considered. According to Giancotti (2012), B. ruziziensis is suited for the implementation of a no-tillage system because it has reduced clumping and rapid death, thereby favouring mechanised sowing.

Table 4 shows that the macroporosity values were inferior to the forest in all systems and depths evaluated, except for the intercropped second crop at the depth of 30-40 $\mathrm{cm}$. When analysing the pore size distribution, pores $>73 \mu \mathrm{m}$ highlighted the effect of the Brachiaria species throughout the layer exploited by the roots, which formed biopores favourable to the subsequent crop, thus confirming results obtained by Magalhães et al. (2009).

According to Carducci et al. (2011), the soils overlying the Brazilian Cerrado have high drainable porosity $(>145 \mu \mathrm{m})$ and elevated pore volume with extremely small diameter $(<2.9 \mu \mathrm{m})$ and no significant intermediate pore volume, which causes low plant water availability. Notably, the insertion of marandu grass increased the pore volume between 50 and $9.0 \mu \mathrm{m}$ in the surface layers (Table 4). This size class is responsible for the retention of water readily available to plants, which contributes to resilience of the production system to climate risks common in the region under study (Severiano et al., 2013).

Physical improvement of the soil shows the importance of including forage plants in soil structure, thus allowing the exploitation of the soil profile by the roots into deeper layers due to increased water availability for the crops (Chioderoli et al., 2012). Considering that soil management promotes changes in the soil water content, field capacity, permanent wilting point, availability of $\mathrm{O}_{2}$ and mechanical resistance to the root system, the LLWR of the soil was determined (Figure 1). 
Table 4. Temporal distribution of soil bulk density (Bd) and pore size of the dystrophic Red Latosol at five depths and under different systems of soil use and management during the between-crop season of soybean cultivation

\begin{tabular}{|c|c|c|c|c|c|c|c|c|c|c|}
\hline \multirow{2}{*}{ Management system } & \multirow{2}{*}{ Bd } & \multicolumn{6}{|c|}{ Pore diameter $(\mu \mathrm{m})$} & \multirow{2}{*}{$\mathbf{T P}$} & \multirow{2}{*}{ Macro } & \multirow{2}{*}{ Micro } \\
\hline & & $>145$ & $145-73$ & $73-50$ & $50-9.0$ & $9.0-2.9$ & $<2.9$ & & & \\
\hline & $\mathrm{kg} \mathrm{dm}{ }^{-3}$ & & & & L & $\mathrm{Im}^{3} \mathrm{dm}^{-3}$ & & & & \\
\hline & & & & & & $0-5 \mathrm{~cm}$ & & & & \\
\hline B. brizantha & $1.36 \mathrm{~b}$ & $0.09 \mathrm{~b}$ & $0.04 \mathrm{~b}$ & $0.01 \mathrm{a}$ & $0.08 \mathrm{a}$ & $0.05 \mathrm{a}$ & $0.22 \mathrm{a}$ & $0.49 \mathrm{~b}$ & $0.14 \mathrm{~b}$ & $0.35 \mathrm{a}$ \\
\hline Intercropped second crop & $1.42 \mathrm{a}$ & $0.09 \mathrm{~b}$ & $0.03 \mathrm{~b}$ & $0.02 \mathrm{a}$ & $0.06 \mathrm{~b}$ & $0.04 \mathrm{a}$ & $0.23 \mathrm{a}$ & $0.47 \mathrm{~b}$ & $0.13 \mathrm{~b}$ & $0.34 \mathrm{a}$ \\
\hline Single second crop & $1.43 \mathrm{a}$ & $0.06 \mathrm{c}$ & $0.02 \mathrm{c}$ & $0.03 \mathrm{a}$ & $0.07 \mathrm{ab}$ & $0.04 \mathrm{a}$ & $0.24 \mathrm{a}$ & $0.46 \mathrm{~b}$ & $0.12 \mathrm{~b}$ & $0.34 \mathrm{a}$ \\
\hline Fallow & $1.45 \mathrm{a}$ & $0.06 \mathrm{c}$ & $0.02 \mathrm{c}$ & $0.03 \mathrm{a}$ & $0.06 \mathrm{~b}$ & $0.04 \mathrm{a}$ & $0.24 \mathrm{a}$ & $0.45 \mathrm{~b}$ & $0.11 \mathrm{~b}$ & $0.34 \mathrm{a}$ \\
\hline Forest & $1.08 \mathrm{c}$ & $0.27 \mathrm{a}$ & $0.09 \mathrm{a}$ & $0.03 \mathrm{a}$ & $0.01 \mathrm{c}$ & $\begin{array}{l}0.03 \mathrm{~b} \\
5-10 \mathrm{~cm}\end{array}$ & $0.17 \mathrm{~b}$ & $0.59 \mathrm{a}$ & $0.38 \mathrm{a}$ & $0.21 \mathrm{~b}$ \\
\hline B. brizantha & $1.34 \mathrm{~b}$ & $0.11 \mathrm{~b}$ & $0.04 \mathrm{~b}$ & $0.01 \mathrm{a}$ & $0.08 \mathrm{a}$ & $0.04 \mathrm{a}$ & $0.22 \mathrm{a}$ & $0.50 \mathrm{~b}$ & $0.16 \mathrm{~b}$ & $0.34 \mathrm{a}$ \\
\hline Intercropped second crop & $1.44 \mathrm{a}$ & $0.07 \mathrm{c}$ & $0.04 \mathrm{bc}$ & $0.03 \mathrm{a}$ & $0.06 \mathrm{~b}$ & $0.04 \mathrm{a}$ & $0.22 \mathrm{a}$ & $0.46 \mathrm{~b}$ & $0.14 \mathrm{~b}$ & $0.32 \mathrm{a}$ \\
\hline Single second crop & $1.40 \mathrm{a}$ & $0.08 \mathrm{c}$ & $0.03 \mathrm{c}$ & $0.02 \mathrm{a}$ & $0.07 \mathrm{a}$ & $0.04 \mathrm{a}$ & $0.23 \mathrm{a}$ & $0.47 \mathrm{~b}$ & $0.13 \mathrm{~b}$ & $0.34 \mathrm{a}$ \\
\hline Fallow & $1.40 \mathrm{a}$ & $0.07 \mathrm{c}$ & $0.03 \mathrm{c}$ & $0.03 \mathrm{a}$ & $0.06 \mathrm{~b}$ & $0.05 \mathrm{a}$ & $0.23 \mathrm{a}$ & $0.47 \mathrm{~b}$ & $0.13 \mathrm{~b}$ & $0.34 \mathrm{a}$ \\
\hline Forest & $1.17 \mathrm{c}$ & $0.21 \mathrm{a}$ & $0.09 \mathrm{a}$ & $0.03 \mathrm{a}$ & $0.01 \mathrm{c}$ & $\begin{array}{l}0.03 \mathrm{~b} \\
10-20 \mathrm{cr}\end{array}$ & $0.19 \mathrm{~b}$ & $0.56 \mathrm{a}$ & $0.33 \mathrm{a}$ & $0.23 \mathrm{~b}$ \\
\hline B. brizantha & $1.37 \mathrm{a}$ & $0.08 \mathrm{~b}$ & $0.03 \mathrm{~b}$ & $0.03 \mathrm{a}$ & $0.07 \mathrm{a}$ & $0.04 \mathrm{a}$ & $0.23 \mathrm{a}$ & $0.48 \mathrm{~b}$ & $0.14 \mathrm{~b}$ & $0.34 \mathrm{a}$ \\
\hline Intercropped second crop & $1.35 \mathrm{a}$ & $0.08 \mathrm{~b}$ & $0.04 \mathrm{~b}$ & $0.04 \mathrm{a}$ & $0.07 \mathrm{a}$ & $0.04 \mathrm{a}$ & $0.22 \mathrm{ab}$ & $0.49 \mathrm{~b}$ & $0.16 \mathrm{~b}$ & $0.33 \mathrm{a}$ \\
\hline Single second crop & $1.32 \mathrm{~b}$ & $0.09 \mathrm{~b}$ & $0.04 \mathrm{~b}$ & $0.03 \mathrm{a}$ & $0.08 \mathrm{a}$ & $0.04 \mathrm{a}$ & $0.22 \mathrm{ab}$ & $0.50 \mathrm{~b}$ & $0.16 \mathrm{~b}$ & $0.34 \mathrm{a}$ \\
\hline Fallow & $1.39 \mathrm{a}$ & $0.07 \mathrm{~b}$ & $0.04 \mathrm{~b}$ & $0.04 \mathrm{a}$ & $0.07 \mathrm{a}$ & $0.04 \mathrm{a}$ & $0.22 \mathrm{ab}$ & $0.48 \mathrm{~b}$ & $0.15 \mathrm{~b}$ & $0.33 \mathrm{a}$ \\
\hline Forest & $1.27 \mathrm{~b}$ & $0.14 \mathrm{a}$ & $0.09 \mathrm{a}$ & $0.04 \mathrm{a}$ & $0.01 \mathrm{~b}$ & $\begin{array}{l}0.04 \mathrm{a} \\
20-30 \mathrm{cr}\end{array}$ & $0.20 \mathrm{~b}$ & $0.52 \mathrm{a}$ & $0.27 \mathrm{a}$ & $0.25 \mathrm{~b}$ \\
\hline B. brizantha & $1.33 \mathrm{a}$ & $0.09 \mathrm{~b}$ & $0.05 \mathrm{~b}$ & $0.04 \mathrm{a}$ & $0.07 \mathrm{a}$ & $0.04 \mathrm{a}$ & $0.21 \mathrm{a}$ & $0.50 \mathrm{a}$ & $0.18 \mathrm{~b}$ & $0.32 \mathrm{a}$ \\
\hline Intercropped second crop & $1.33 \mathrm{a}$ & $0.09 \mathrm{~b}$ & $0.06 \mathrm{~b}$ & $0.03 \mathrm{a}$ & $0.06 \mathrm{a}$ & $0.04 \mathrm{a}$ & $0.22 \mathrm{a}$ & $0.50 \mathrm{a}$ & $0.18 \mathrm{~b}$ & $0.32 \mathrm{a}$ \\
\hline Single second crop & $1.33 \mathrm{a}$ & $0.09 \mathrm{~b}$ & $0.05 \mathrm{~b}$ & $0.04 \mathrm{a}$ & $0.06 \mathrm{a}$ & $0.04 \mathrm{a}$ & $0.22 \mathrm{a}$ & $0.50 \mathrm{a}$ & $0.18 \mathrm{~b}$ & $0.32 \mathrm{a}$ \\
\hline Fallow & $1.33 \mathrm{a}$ & $0.10 \mathrm{~b}$ & $0.05 \mathrm{~b}$ & $0.04 \mathrm{a}$ & $0.05 \mathrm{a}$ & $0.04 \mathrm{a}$ & $0.22 \mathrm{a}$ & $0.50 \mathrm{a}$ & $0.19 \mathrm{~b}$ & $0.31 \mathrm{a}$ \\
\hline Forest & $1.28 \mathrm{a}$ & $0.13 \mathrm{a}$ & $0.12 \mathrm{a}$ & $0.04 \mathrm{a}$ & $0.01 \mathrm{~b}$ & $\begin{array}{l}0.03 \mathrm{a} \\
30-40 \mathrm{cr}\end{array}$ & $0.19 \mathrm{a}$ & $0.52 \mathrm{a}$ & $0.29 \mathrm{a}$ & $0.23 \mathrm{~b}$ \\
\hline B. brizantha & $1.31 \mathrm{a}$ & $0.11 \mathrm{a}$ & $0.07 \mathrm{~b}$ & $0.03 \mathrm{a}$ & $0.04 \mathrm{a}$ & $0.04 \mathrm{a}$ & $0.22 \mathrm{a}$ & $0.51 \mathrm{a}$ & $0.21 \mathrm{~b}$ & $0.30 \mathrm{a}$ \\
\hline Intercropped second crop & $1.28 \mathrm{a}$ & $0.13 \mathrm{a}$ & $0.07 \mathrm{~b}$ & $0.04 \mathrm{a}$ & $0.04 \mathrm{a}$ & $0.04 \mathrm{a}$ & $0.20 \mathrm{a}$ & $0.52 \mathrm{a}$ & $0.24 \mathrm{ab}$ & $0.28 \mathrm{a}$ \\
\hline Single second crop & $1.31 \mathrm{a}$ & $0.12 \mathrm{a}$ & $0.06 \mathrm{~b}$ & $0.04 \mathrm{a}$ & $0.04 \mathrm{a}$ & $0.04 \mathrm{a}$ & $0.21 \mathrm{a}$ & $0.51 \mathrm{a}$ & $0.22 \mathrm{~b}$ & $0.29 \mathrm{a}$ \\
\hline Fallow & $1.32 \mathrm{a}$ & $0.13 \mathrm{a}$ & $0.06 \mathrm{~b}$ & $0.03 \mathrm{a}$ & $0.04 \mathrm{a}$ & $0.03 \mathrm{a}$ & $0.21 \mathrm{a}$ & $0.50 \mathrm{a}$ & $0.22 \mathrm{~b}$ & $0.28 \mathrm{a}$ \\
\hline Forest & $1.28 \mathrm{a}$ & $0.12 \mathrm{a}$ & $0.12 \mathrm{a}$ & $0.02 \mathrm{a}$ & $0.02 \mathrm{a}$ & $0.04 \mathrm{a}$ & $0.20 \mathrm{a}$ & $0.52 \mathrm{a}$ & $0.26 \mathrm{a}$ & $0.26 \mathrm{a}$ \\
\hline
\end{tabular}

TP: Total porosity; Macro: Macropores; Micro: Micropores. Within each depth, the means that have the same letter in the column are not different from one another according to Tukey's test $(p<0.05)$.

Analysis of the LLWR reinforced the effect of $B$. ruziziensis on the soil structure. Due to its low potential for physical recovery, the soil had lower LLWR amplitudes for plants in the surface layers, and the lower limit was found up to a $20 \mathrm{~cm}$ depth, resulting in soil resistance to penetration at this depth (Figure 1). This pattern was also observed in the single second crop system, but the fallow system showed physical limitations at a depth of $30 \mathrm{~cm}$.

In regard to the cultivation of $B$. brizantha in the soybean between-crop season over five years, structural improvements were observed in the soil, resulting in an increase of approximately $25 \%$ in the amplitude of the LLWR due to the reduction of soil water content, corresponding to limiting penetration resistance values similar to the permanent wilting point. Lima et al. (2012a) also showed a higher LLWR with the cultivation of $B$. brizantha.

In all the between-crop season management systems studied, it was observed that water availability assessed using the LLWR exceeded the forest area in the surface layer $(0-20 \mathrm{~cm})$, showing, however, similar values in the deepest layers $(>20 \mathrm{~cm})$, which was consistent with the findings of Oliveira et al. (2004). In addition, table 4 indicates that the action of management systems with the absence of soil disturbance occurred only on the soil surface.

These results showed that the occurrence of soil compaction with an approximate $30 \%$ increase in $\mathrm{Bd}$ in the management systems under study, particularly 
with $B$. brizantha, can be characterised as beneficial in terms of water retention, without having oxygen limitations for plant root growth in the available water range (Severiano et al., 2011), thus promoting further diffusion of nutrients, particularly P (Santos et al., 2005), due to higher soil/root contact. For the other systems, the increase in $\theta_{\mathrm{FC}}$ was counteracted by a larger penetration resistence, thus resulting in no increase in LLWR.

Under natural conditions and from a physical standpoint, oxidic Latosols produce sub-optimal conditions for plant growth because they have reduced development of textural pores responsible for water retention processes (Vollant-Tuduri et al., 2005; Reatto et al., 2007; Carducci et al., 2011). In addition, the compaction of these soils is essentially an inevitable process (Assouline et al., 1997), even under dry soil conditions, due to their low load-bearing capacity (Severiano et al., 2013). It is suggested that the transformation of macropores into micropores caused by compression of the soil may result in increases in crop productivity, especially in drier years (Richart et al., 2005; Beutler et al., 2008; Freddi et al., 2009).

The presence of mulch on the soil surface from the drying of grasses during crop rotations reduces water

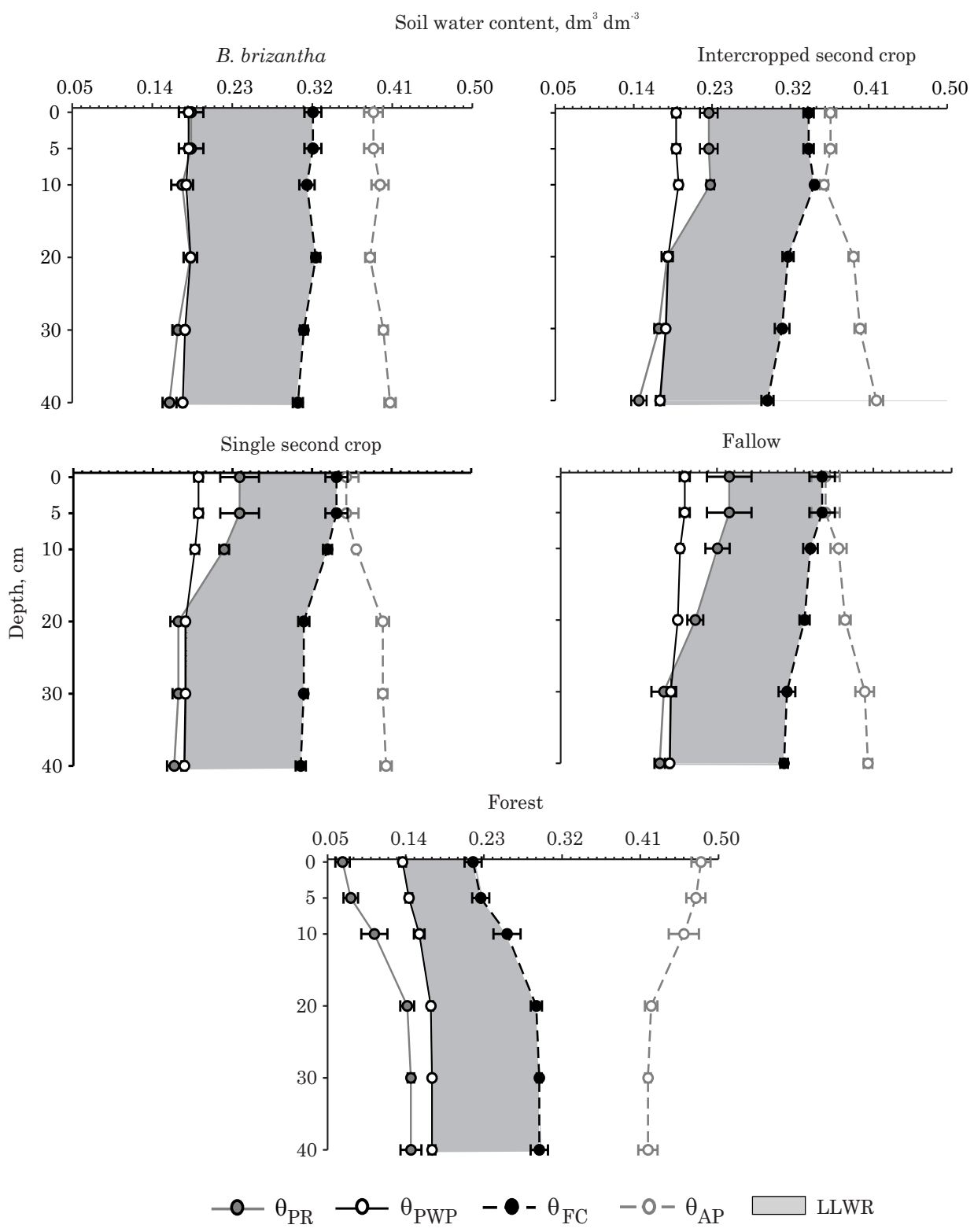

Figure 1. Variation of soil water content $(\theta)$ at different depths for the critical limits of soil resistance to penetration $\left(\theta_{\mathrm{PR}}\right)$, permanent wilting point $\left(\theta_{\mathrm{PWP}}\right)$, field capacity $\left(\theta_{\mathrm{FC}}\right)$ and aeration porosity $\left(\theta_{\mathrm{AP}}\right)$ of the dystrophic Red Latosol under different systems of soil use and management during the between-crop season of soybean cultivation. LLWR: Least Limiting Water Range. 
loss by evaporation (Andrade et al., 2011), due to the lower thermal oscillation on the surface layer (Panachuki et al., 2011), thereby contributing to greater water availability to crops in succession (Braida et al., 2006; Chioderoli et al., 2012). In this respect, the presence of mulch on the surface and the structural improvement of the soil afforded by $B$. brizantha can promote a better edaphic environment in the soil, thus resulting in higher yield of successive summer crops.

Thus, when evaluating the development of soybean cultivation during the 2011/2012 harvest, Caetano et al. (2012) found that soybean grain yield in the area with $B$. brizantha as a cover crop during the between-crop season is approximately $26 \%$ higher (increase of $688 \mathrm{~kg} \mathrm{ha}^{-1}$ ) in relation to the other systems, which, in turn, do not differ from one another. This result is due to the improved soil chemistry (Table 3) and structure (Table 4; Figure 1) in this system.

Maintaining the production systems as fallow during the between-crop season is a strategy that has been consistently adopted by farmers in the Cerrado region, which may compromise conservation management of the soil. Conversely, grasses of the genus Brachiaria have emerged as options for mulch production for no-tillage because of their high production of plant residues, accumulated nutrients and chemical-bromatological composition, which is unfavourable to decomposition (Nepomuceno et al., 2012).

When cultivated in the between-crop season, $B$. ruziziensis improved the chemical properties of the soil due to its perennial nature and nutrient cycling (Table 3). As a function of its prostrated growth and reduced clumping, B. ruziziensis has been considered by many Brazilian farmers as the plant cover best suited for intercropping with grains during the second crop. Due to its ease of drying, B. ruziziensis can also be used as a cover crop (Machado \& Assis, 2010).

Although intercropping of $B$. brizantha with annual crops is also feasible (Calonego et al., 2011; Chioderoli et al., 2012; Maia et al., 2014) in areas cultivated with soybean varieties of late maturation or in regions where rainfall causes a second crop to be a risky activity, its monocrop cultivation assumes a prominent role in integrated production systems. In addition to amendments to soil fertility (Table 3), this Brachiaria species improved soil structure and increased the amplitude of LLWR, which benefited plant water availability (Figure 1).

Therefore, it is suggested that the increased productivity of soybeans in succession to cultivation of B. brizantha (Caetano et al., 2012) justifies its recommendation as an important management strategy, with possible uses of higher doses of desiccants to control the species in question.

\section{CONCLUSIONS}

1. Under the study conditions, the conversion of native vegetation areas into agricultural fields altered the chemical properties of the soil at all depths evaluated.

2. The major physical-hydric soil alterations occurred up to $10 \mathrm{~cm}$ of depth, due to the effects of root systems on soil structure.

3. The cultivation of $B$. brizantha as a cover crop during the between-crop season of summer crops increased soil water availability, which is important for agricultural activities in the Cerrado region.

\section{LITERATURE CITED}

ANDRADE, R.S.; STONE, L.F. \& SILVEIRA, P.M. Culturas de cobertura e qualidade física de um Latossolo em plantio direto. R. Bras. Eng. Agríc. Amb., 13:411-418, 2009.

ANDRADE, J.G.; SEGUI, J.P.; CARLESSO, R.; TROIS, C. \& KNIES, A.E. Pérdidas de agua por evaporación en maíz con siembra convencional y directa para diferentes niveles de cobertura muerta. I. Resultados experimentales. R. Ci. Técn. Agropec., 20:29-36, 2011.

ASSOULINE, S.; TAVARES FILHO, J. \& TESSIER, D. Effect of compaction on soil physical and hydraulic properties: Experimental results and modeling. Soil Sci. Soc. Am. J., 61:390-398, 1997.

BEUTLER, A.N.; CENTURION, J.F.; SILVA, A.P.; CENTURION, M.A.P.C.; LEONEL, C.L. \& FREDDI, O.S. Soil compaction by machine traffic and least limiting water range related to soybean yield. Pesq. Agropec. Bras., 43:1591-1600, 2008.

BLAINSKI, E.; TORMENA, C.A.; GUIMARÃES, R.M.L. \& NANNI, M.R. Qualidade física de um Latossolo sob plantio direto influenciada pela cobertura do solo. R. Bras. Ci. Solo, 36:79-87, 2012.

BOUMA, J. Influence of soil macroporosity on environmental quality. Adv. Agron., 46:2-37, 1991.

BRAIDA, J.A.; REICHERT, J.M.; VEIGA, M. \& REINERT, D.J. Resíduos vegetais na superfície e carbono orgânico do solo e suas relações com a densidade máxima obtida no ensaio Proctor. R. Bras. Ci. Solo, 30:605-614, 2006.

CAETANO, J.O.; SANTOS, F.L.; BENITES, V.M.; CARNEIRO, M.A.C.; FERREIRA FILHO, W.C.; GUIMARÃES, G.S.; BARCELOS, J.G.E. \& PAULINO, H.B. Atributos bioquímicos, enzimáticos e físicos do solo, ciclagem de nutrientes e rendimento da soja após entressafra de Brachiaria sp. In: FERTBIO, Maceio, 2012. Anais... Maceio, AL, Sociedade Brasileira de Ciência do Solo, 2012. CDROM

CALONEGO, J.C.; BORGHI, E. \& CRUSCIOL, C.A.C. Intervalo hídrico ótimo e compactação do solo com cultivo consorciado de milho e braquiária. R. Bras. Ci. Solo, 35:2183-2190, 2011. 
CARDUCCI, C.E.; OLIVEIRA, G.C.; SEVERIANO, E.C. \& ZEVIANI, W.M. Modelagem da curva de retenção de água de Latossolos utilizando a equação duplo van Genuchten. R. Bras. Ci. Solo, 35:77-86, 2011.

CARNEIRO, M.A.C.; SOUZA, E.D.; REIS, E.F.; PEREIRA, H.S. \& AZEVEDO, W.R. Atributos físicos, químicos e biológicos de solo de cerrado sob diferentes sistemas de uso e manejo. R. Bras. Ci. Solo, 33:147-157, 2009.

CERRI, C.C.; CARVALHO, J.L.N.; NASCIMENTO, A.M. \& MIRANDA, S.H.G. Agricultura de baixo carbono. O que a ciência do solo tem a ver com isso? B. Inf. SBCS, 37:1319, 2012 .

CHIODEROLI, C.A.; MELLO, L.M.M.; GRIGOLLI, P.J.; FURLANI, C.E.A.; SILVA, J.O.R. \& CESARIN, A.L. Atributos físicos do solo e produtividade de soja em sistema de consórcio milho e braquiária. R. Bras. Eng. Agríc. Amb., 16:37-43, 2012.

EMPRESA BRASILEIRA DE PESQUISA AGROPECUÁRIA EMBRAPA. Centro Nacional de Pesquisas de Solos. Manual de métodos de análises de solo. 2.ed. Rio de Janeiro, 2011. 230p.

EMPRESA BRASILEIRA DE PESQUISA AGROPECUÁRIA EMBRAPA. Centro Nacional de Pesquisa de Solos. Sistema brasileiro de classificação de solos. 3.ed. Brasília, Produção de Informação, 2013. 353p.

FERREIRA, D.F. Sisvar: A computer statistical analysis system. Ci. Agrotec., 35:1039-1042, 2011.

FLÁVIO NETO, J. Qualidade estrutural do solo, produção de massa seca e palhada de forrageiras do gênero Brachiaria em sistema de integração agricultura-pecuária. Rio Verde, Instituto Federal Goiano, 2012. 38p. (Dissertação de Mestrado)

FREDDI, O.S.; CENTURION, J.F.; DUARTE, A.P. \& PERES, F.S.C. Compactação do solo e produção de cultivares de milho em Latossolo Vermelho: II - Intervalo hídrico ótimo e sistema radicular. R. Bras. Ci. Solo, 33:805-818, 2009.

GALHARTE, C.A. \& CRESTANA, S. Avaliação do impacto ambiental da integração lavoura-pecuária: Aspecto conservação ambiental no cerrado. R. Bras. Eng. Agríc. Amb., 14:1202-1209, 2010.

GARCIA, R.A.; CRUSCIOL, C.A.C.; CALONEGO, J.C. \& ROSOLEM, C.A. Potassium cycling in a corn-brachiaria cropping system. Eur. J. Agron., 28:579-585, 2008.

GIANCOTTI, P.R.F. Período de dessecação de Brachiaria ruziziensis e $B$. brizantha antecedendo o plantio direto do girassol. Jaboticabal, Universidade Estadual Paulista. 2012. 49p. (Dissertação de Mestrado)

JAKELAITIS, A.; SILVA, A.A.; SANTOS, J.B. \& VIVIAN, R. Qualidade da camada superficial de solo sob mata, pastagens e áreas cultivadas. Pesq. Agropec. Trop., 38:118$127,2008$.

KADŽIENĖ, G.; MUNKHOLM, L.J. \& MUTEGI, J.K. Root growth conditions in the topsoil as affected by tillage intensity. Geoderma, 166:66-73, 2011.

KÖPPEN, W.P. Grundriss der Klimakunde. Berlin, Walter de Gruyter, 1931
LIMA, C.L.R.; MIOLA, E.C.C.; TIMM, L.C.; PAULETTO, E.A. \& SILVA, A. Soil compressibility and least limiting water range of a constructed soil under cover crops after coal mining in Southern Brazil. Soil Till. Res., 124:190-195, 2012b.

LIMA, V.M.P.; OLIVEIRA, G.C.; SERAFIM, M.E.; CURI, N. \& EVANGELISTA, A.R. Intervalo Hídrico Ótimo como indicador de melhoria da qualidade estrutural de Latossolo degradado. R. Bras. Ci. Solo, 36:71-78, 2012a.

MACHADO, L.A.Z. \& ASSIS, P.G.G. Produção de palha e forragem por espécies anuais e perenes em sucessão à soja. Pesq. Agropec. Bras., 45:415-422, 2010.

MAGALHÃES, E.N.; OLIVEIRA, G.C.; SEVERIANO, E.C.; COSTA, K.A.P. \& CASTRO, M.B. Recuperação estrutural e produção de capim-tifton 85 em um Argissolo VermelhoAmarelo compactado. Ci. Anim. Bras., 10:68-76, 2009.

MAIA, G.A.; COSTA, K.A.P.; SEVERIANO, E.C.; EPIFANIO, P.S.; FLÁVIO NETO, J.; RIBEIRO, M.G.; FERNANDES, P.B.; SILVA, J.F. \& GONÇALVES, W.G. Yield and chemical composition of Brachiaria forage grasses in the offseason after corn harvest. Am. J. Plant Sci., 5:933-941, 2014.

McNEILL, A.M. \& PENFOLD, C.M. Agronomic management options for phosphorus in Australian dryland organic and low-input cropping systems. Crop Past. Sci., 60:163-182, 2009.

NASCENTE, A.S. \& CRUSCIOL, C.A.C. Cover crops and herbicide timing management on soybean yield under no-tillage system. Pesq. Agropec. Bras., 47:187-192, 2012.

NASCENTE, A.S.; LI, Y.C. \& CRUSCIOL, C.A.C. Cover crops and no-till effects on physical fractions of soil organic matter. Soil Till. Res., 130:52-57, 2013.

NEPOMUCENO, M.P.; VARELA, R.M.; ALVES, P.L.C.A. \& MARTINS, J.V.F. Períodos de dessecação de Brachiaria ruziziensis e seu reflexo na produtividade da soja $R R$. Planta Daninha, 30:557-565, 2012.

OLIVEIRA, G.C.; DIAS JUNIOR, M.S.; RESCK, D.V.S. \& CURI, N. Caracterização química e físico-hídrica de um Latossolo Vermelho após vinte anos de manejo e cultivo do solo. R. Bras. Ci. Solo, 28:327-336, 2004.

OLIVEIRA, G.C.; SEVERIANO, E.C. \& MELLO, C.R. Dinâmica da resistência à penetração de um Latossolo Vermelho da microrregião de Goiânia, GO. R. Bras. Eng. Agríc. Amb., 11:265-270, 2007.

PACHECO, L.P.; LEANDRO, W.M.; MACHADO, P.L.O.A.; ASSIS, R.L.; COBUCCI, T.; MADARI, B.E. \& PETTER, F.A. Produção de fitomassa e acúmulo e liberação de nutrientes por plantas de cobertura na safrinha. Pesq. Agropec. Bras., 46:17-25, 2011.

PANACHUKI, E.; BERTOL, I.; SOBRINHO, T.A.; OLIVEIRA, P.T.S. \& RODRIGUES, D.B.B. Perdas de solo e de água e infiltração de água em Latossolo Vermelho sob sistemas de manejo. R. Bras. Ci. Solo, 35:1777-1785, 2011.

REATTO, A.; BRUAND, A.; SILVA, E.M.; MARTINS, E.S. \& BROSSARD, M. Hydraulic properties of the diagnostic horizon of Latosol of a regional toposequence across the Brazilian central plateau. Geoderma, 139:51-59, 2007. 
RICHART, A.; TAVARES FILHO, J.; BRITO, O.R.; LLANILLO, R.F. \& FERREIRA, R. Compactação do solo: Causas e efeitos. Semina, 26:321-344, 2005.

SANTOS, G.A.; DIAS JUNIOR, M.S.; GUIMARÃES, P.T.G. \& FURTINI NETO, A.E. Diferentes graus de compactação e fornecimento de fósforo influenciando no crescimento de plantas de milho (Zea mays L.) cultivadas em solos distintos. Ci. Agrotec., 29:740-752, 2005.

SCHIAVO, J.A.; ROSSET, J.S.; PEREIRA, M.G. \& SALTON, J.C. Índice de manejo de carbono e atributos químicos de Latossolo Vermelho sob diferentes sistemas de manejo. Pesq. Agropec. Bras., 46:1332-1338, 2011.

SEVERIANO, E.C.; OLIVEIRA, G.C.; DIAS JÚNIOR, M.S.; COSTA, K.A.P.; SILVA, F.G. \& FERREIRA FILHO, S.M. Structural changes in Latosols of the cerrado region: I Relationships between soil physical properties and least limiting water range. R. Bras. Ci. Solo, 35:773-782, 2011.

SEVERIANO, E.C.; OLIVEIRA, G.C.; DIAS JUNIOR, M.S.; CURI, N.; COSTA, K.A.P. \& CARDUCCI, C.E. Preconsolidation pressure, soil water retention characteristics, and texture of Latosols in the Brazilian Cerrado. Soil Res., 51:193-202, 2013.
SILVA, A.P.; KAY, B.D.; TORMENA, C.A. \& IMHOFF, S. Least limiting water range of soils. In: LAL, R., org. Encyclopedia of soil science. New York, 2006. v.1, p.10261029.

SIlvA, R.F.; GUIMARÃES, M.F.; AQUinO, A.M. \& MERCANTE, F.M. Análise conjunta de atributos físicos e biológicos do solo sob sistema de integração lavourapecuária. Pesq. Agropec. Bras., 46:1277-1283, 2011.

SILVEIRA, P.M. \& STONE, L.F. Teores de nutrientes e de matéria orgânica afetados pela rotação de culturas e sistema de preparo do solo. R. Bras. Ci. Solo, 25:387-394, 2001.

SOUSA, D.M.G. \& LOBATO, E. Cerrado: Correção do solo e adubação. 2.ed. Brasília, Embrapa Informação Tecnológica, 2004. 416p.

TOLLEFSON, J. The global farm. Nature, 466:554-556, 2010.

VOLLANT-TUDURI, N.; BRUAND, A.; BROSSARD, M.; BALBINO, L.C.; OLIVEIRA, M.I.L. \& MARTINS, E.S. Mass proportion of microaggregates and bulk density in a Brazilian clayey Oxisol. Soil Sci. Soc. Am. J., 69:5591564, 2005. 